\title{
KOMUNIKASI ANTARBUDAYA ETNIS LOKAL DENGAN ETNIS PENDATANG: STUDI PADA MAHASISWA/I FAKULTAS ADAB DAN ILMU BUDAYA UIN SUNAN KALIJAGA YOGYAKARTA
}

\author{
Eko Saputra \\ eko322590@gmail.com \\ Kajian Komunikasi dan Masyarakat Islam \\ Pascasarjana UIN Sunan Kalijaga Yogyakarta
}

\section{Article Info}

\section{Keyword:}

Intercultural communication, cultural interaction and acculturation, local ethnicity and immigrant ethnicity.

\begin{abstract}
This study examines the behaviors, interactions and acculturation of intercultural communication with students Faculty of Adab dan Ilmu Budaya at the Sunan Kalijaga State Islamic University in Yogyakarta (UIN-SUKA). Intercultural communication for new students at the Faculty Adab dan Ilmu Budaya UIN-SUKA has been become an annual tradition for them to get to know each other, learn and understand the cultural characteristics of their respective faculty friends. In this paper, the author am willing explore the intercultural communication of local ethnicities with ethnic migrants in the Faculty of Adab and Ilmu Budaya at UIN-SUKA which covers the introduction, adaptation, symbolic interactionalism and cultural accuracy. Answer these various questions, the author made a qualitative methodological approach by conducting interviews and interlocutor to some of the Faculty of Adab dan Ilmu Budaya UIN-SUKA of Culture students. The results of this study show that their intercultural communication is very intensive to their friends who are of different cultures. They communicate between their cultures in classrooms, halls, lobbies, canteens, seats, and campus grounds. Then, it is not uncommon for them to do intercultural collaboration at certain events, for example Pekan Budya, Disaster Care Students, and Social Solidarity. The contribution of this study is to provide readers with literature about intercultural communication with new students who have cultural differences, because every year new students experience the same case.
\end{abstract}

Copyright (C) 2019 Interaksi: Jurnal Ilmu Komunikasi. All rights reserved.

\section{PENDAHULUAN}

Era Globalisasi ini, perubahan sosialmasyarakat tidak dapat dielakkan lagi. Salah satu faktor utama yang menjadi perubahan dalam sosialmasyarakat adalah sentuhan budaya (cultural encounters) baik dalam maupun luar (Astuti, 2014: 305). Budaya akan selalu mengalami perubahan seiring dengan perkembangan zaman. Apalagi di zaman modern ini, pesatnya ilmu pengetahuan dan teknologi dalam bidang komunikasi membuat orang lebih mudah mengenal budaya orang lain dari berbagai latarbelakang budaya yang berbeda-beda. Tidak hanya mencakup lokal, namun antar daerah, wilayah, maupun antar negara (Astuti, 2014: 305; Heryadi dan Silvana, 2013: 95). Terutama, ini terjadi pada masyarakat perkotaan yang memiliki latarbelakang kebudayaan yang berbeda-beda. Hal ini membuat masyarakat semakin terbuka, saling mengenal, dan saling mempelajari satu dengan yang lainnya. Lebih lanjut lagi saling mengakulturasi antar budaya yang berbeda-beda (Astuti 2014: 305; Rusdiyanta 2009: 48).

Berbagai cara dan pendekatan yang manusia lakukan untuk membangun komunikasi antarbudaya. Artinya, komunikasi yang mereka lakukan pada orang lain maupun kelompok lain adalah sebuah pertukaran kebudayaan, perpaduan dan akulturasi (Astuti, 2014: 305). Individu yang memasuki lingkungan baru berarti melakukan kontak antarbudaya, maka komunikasi antarbudaya menjadi hal yang tidak terelakan. Dengan demikian, komunikasi antarbudaya menjadi kewajiban yang harus dilakukan oleh seseorang untuk mengenal, mempelajari, dan sampai pada perpaduan antarbudaya.

Menurut Aloweri, Andrea L. Rich dan Dennis 
M. Ogawa sebagaimana dikutip oleh Armawati Arbi (2003: 186), komunikasi antarbudaya adalah komunikasi antara orang-orang yang berbeda kebudayaan. Misalnya antara suku bangsa, etnik, ras dan kelas sosial. Sementara menurut Guo Ming Chen dan Willian J. Starosta sebagaimana dikutip oleh Deddy Mulyana (2003: xii) berpendapat bahwa komunikasi antar budaya adalah proses negosiasi atau pertukaran sistem simbolik yang membimbing perilaku manusia dan membatasi mereka dalam menjalankan fungsinya sebagai kelompok (Heryadi dan Silvana 2013: 97). Selanjutnya, komunikasi antar budaya (intercurtural communicaution) adalah proses pertukaran pikiran dan makna antar orang-orang berbeda budaya. Ketika komunikasi terjadi antar orang-orang berbeda bangsa, kelompok, ras, atau komunikasi bahasa, komunikasi tersebut disebut komunikasi antarbudaya (Heryadi dan Silvana 2013: 97).

Sesuai dengan penjelasan di atas, dapat dipahami juga bahwa komunikasi antarbudaya muncul sebagai aktivitas komunikasi yang terjadi antara mahasiswa imigran dengan mahasiswa lokal. Seperti aktivitas kampus yang menyebabkan mereka berbaur dengan teman-temannya satu sama lain yang mempunyai latarbelakang budaya yang berbeda (Fisher, Aubrey 1986:231). Ketika terjadinya kontak simbolik antara mahasiswa satu dengan yang lainnya maka di sana terjadinya sebuah aktivitas komunikasi (Heryadi dan Silvana 2013: 97). Ketika adanya hubungan simbolik antara mereka maka di sana lah mereka mencoba untuk membuka diri pada budaya lain. Menurut Joseph A DeVito (1997: 475-477) kondisi di sekitar kita yang menyebabkan komunikasi antarbudaya semakin penting dirasakan pada saat ini. Di antaranya karena adanya mobilitas manusia, saling ketergantungan ekonomi, teknologi komunikasi, pola imigrasi ataupun kesejahteraan politik. Dalam masyarakat perkotaan laju komunikasi antar budaya selalu berjalan dinamis.

Selengkapnya studi-studi sebelumnya yang membahas tentang komunikasi antarbudaya telah dibahas oleh Lusiana Andriani Lubis (2012: 13-27). Lubis menelisik tentang komunikasi antarbudaya etnis Tionghoa dan Pribumi di Kota Medan. Studinya menjelaskan bahwa agama dan kepercayaan adalah suatu yang hak dan tidak dapat dipisahkan. Akan tetapi, dalam perjalannya waktu tradisi itu akan berubah. Seperti dalam kasus perkawinan antara etnis Tionghoa dan Pribumi. Keyakinan akan dipertaruhkan untuk memperoleh kesepakatan. Komunikasi antarbudaya dapat merubah cara pandang nilai-nilai budaya Tionghoa dengan Pribumi terhadap hak dan kepercayaan. Sehingga dalam pandangan agama pun dapat berubah, kemudian prilaku beragama menjadi berubah ke arah positif dan pandangan terhadap dunia pun berubah berdasarkan kepercayaan nilai-nilai yang dianut oleh masyarakat. Seperti hubungan antara Tionghoa dengan masyarakat pribumi yang semakin baik dan toleran, perkawinan antara Tionghoa dengan Pribumi mengubah keyakinan salah satu di antara keduanya, masuk Islam atau Konghucu. Kemudian, Lubis (2012: 286-294) dalam artikel lain membahas tentang komunikasi antarbudaya Tionghoa dan Pribumi dalam penggunaan bahasa. Hasil studinya menunjukan bahwa keragaman bahasa di Medan unik, terbuka dan toleran. Masyarakat tidak akan mempermasalahkan bahasa selagi pihak-pihak yang terlibat merasa nyaman, tidak diganggu, tidak membuat keributan dan memahami pesan-pesan yang disampaikan.

Berbeda halnya dengan studi yang dilakukan oleh Hernawan (2010: 62-74), yang menelisik tentang komunikasi antarumat berbeda agama: studi kasus sikap sosial dalam keragaman beragama di Kecamatan Cigugur Kabupaten Kuningan Jawa Barat. Temuannya menunjukan bahwa komunikasi antarumat beragama di Cianjur memiliki potensi yang cukup kuat konflik antar kelompok keagamaan. Kemudian dalam temuan Hernawan, komunikasi antarumat beragama di Kabupaten Kuningan Jawa Barat menimbulkan prasangka sosial antar kelompok-kelompok keagamaan, dan juga terjadinya persaingan antar kelompok keagamaan, serta adanya suatu nilai tradisi dan budaya yang mengatur hubungan antar masyarakat maupun kelompok untuk membatasi diri dalam berbaur, berasimilasi. Sehingga menimbulkan perselisihan dan konflik antar mereka.

Beda dari Lubis (2012: 285-294, 2012: 13-27)

dan Hermawan (2010: 62-74), Bahari (2008: 1-12) mengkaji tentang model komunikasi lintas budaya 
dalam resolusi konflik berbasis pranata adat Melalu dan Madura di Kalimantan Barat. Hasil temuannya menunjukan bahwa penyelesaian model komunikasi lintas budaya dalam resolusi konflik kedua adat tersebut melalui 'penyelesaian musyawarah,' yaitu kepala desa bersama kepala adat Melayu dan Madura duduk bersama untuk mencari jalan penyelesaian (resolusi konflik). Peranan tokoh adat dan kepala desan di sini sangat penting. Ketiga tokoh tersebut menjadi wadah dalam penyelesaian konfilik dan pencegahan antar kedua kelompok tersebut. Sejalan dengan studi Bahari (2008: 1-12), Fitri, Mdjid dan Anshari (2016) konflik keagamaan juga terjadi pada masyarakat Rosario Kecamatan Sleman Yogyakarta. Konfilik keagamaan pada tindakan kekerasan dipicu oleh sikap warga masyarakat yang tidak suka pada jemaat Risario. Warga yang tidak suka tersebut melakukan tindakan diskriminasi keagamaan.

Kemudian dari beberapa studi penulis jelaskan di atas, tulisan yang mengkaji tentang komunikasi antarbudaya pada mahasiswa/I belum banyak dilakukan. Studi-studi sebelumnya pada mahasiswa lebih menyoroti tentang negosisasi identitas dan budaya mahasiswa. Seperti studi yang dilakukan oleh Yahya dan Raharjo (2018: 1-6). Selanjutnya, tentang adaptasi komunikasi antara stranger dan culture. Studi ini dilakukan oleh Ghozali dan Rahardjo (2019: 43-52). Kemudian tentang adaptasi lintas budaya dan prilaku komunikasi mahasiswa, studi yang dilakukan oleh Umam (2018: 43-48), kecemasan komunikasi dalam relasi antar etnis studi yang dilakukan oleh Marewa (2016:), hambatan komunikasi antarbudaya studi yang dilakukan oleh Beatrix dan Triputra (2018: 259-265), dan komunikasi budaya studi yang dilakukan oleh Sjofjan dan Azeharie (2018: 409-416). Sementara, studi yang mengkaji tentang komunikasi antarbudaya mahasiswa konteks lokal dan pendatang belum banyak dilakukan. Oleh karena itu, penulis akan mengkaji tentang komunikasi antarbudaya mahasiswa/I Fakultas Adab dan Ilmu Budaya Universitas Islam Negeri Sunan Kalijaga Yogyakarta (UIN-SUKA). Pentingnya studi ini dilakukan adalah untuk melihat bagaimanakah komunikasi antarbudaya mahasiswa/I etnis mahasiswa lokal dengan etnis pendatang.

Berbeda dari studi-studi sebelumnya, artikel ini menelisik tentang komunikasi anarbudaya mahasiswa lokal dengan mahasiswa pendatang: studi pada Fakultas Adab dan Ilmu Bidaya UIN-SUKA. Penulis akan mendiskusikan temuan ini ke dalam interaksi, adaptasi, dan alkuturasi antarbudaya pada mahasiswa Fakultas Adab dan Ilmu Budaya UINSUKA. Kemudian, penulis akan mendiskusikan temuan-temuan ini dengan literatur yang relevan sesuai dengan topik penelitian ini yang terangkum dalam kerangka teoretis dan pembahasan.

\section{RUMUSAN MASALAH}

Secara khusus, artikel ini akan mendiskusikan tiga pertanyaan utama. Di antaranya: apakah mereka membuka diri dengan teman-temannya yang memiliki latarbelakang budaya yang berbeda? Bagaimana bentuk pendekatan yang mereka lakukan tentang komunikasi antarbudaya? dan bagaimana mereka mengakulturasikan kebudayaan mereka yang berbeda?

\section{METODOLOGI PENELITIAN}

Penelitian ini menggunakan metode kualitatif, melalui pendekatan lapangan (file research). Penelitian lapangan dilakukan untuk menggambarkan suatu realitas sosial yang terjadi di masyarakat (Heryadi dan Silvana 2013: 101). Menurut Nasution (dalam Sudjarwo, 2001: 25) metode kualitatif merupakan pendekatan yang didasarkan pada kenyataan lapangan dan apa saja yang dialami oleh responden. Oleh karena itu, sebagai seorang peneliti harus memahami situasi yang terjadi di lapangan. Bagaimana sikap, respon dan tindakan seorang responden. Penulis harus mencatat, mengamati, dan menganalisis setiap aktivitas yang dilakukan oleh responden.

Untuk melihat bagaimana komunikasi antarbudaya yang dilakukan oleh mahasiwa Fakultas Adab dan Ilmu Budaya UIN-SUKA, penulis melakukan pendekatan interaksionisme simbolik, teori dari George Heber Mead (1934) dalam karyanya tentang Mind, Self and Society ('pikiran,' 'diri,' dan 'masyarakat.' Karya tersebut yang kemudian dikembangkan dalam mazab Robert Blumer (Chicago School) (1979) melalui metode kualitatif. Blumer (1979) mengatakan manusia merupakan mahluk yang 
dinamis. Oleh sebab itu, menurut Blumer pendekatan kualitatif adalah pendekatan yang tepat untuk memperdalam analisis subjek peneliti dari pada pendekatan kuantitatif. Karena, dia menilai bahwa manusia adalah makhluk sosial yang dinamis, progresif maka harus dilakukan dengan pendekatan intensif dan langsung. Yaitu melalui metode kualitatif. Seperti berinteraksi dengan responden, penjelasan pengalaman subjek seseorang, motif (keinginan), nilai-nilai yang mendalam dalam dari seseorang dan lain-lain. Bukan sebagai benda mati, seperti dalam pendekatan kualitatif, yaitu melakukan kajian epistemologi dan posivistik. Blumer mengkritik pendekatan positivistik yang dipandang memiliki beberapa kelemahan, seperti tidak dapat menyelidiki tingkah laku seseorang dalam proses penyesuaian, interaksi, dan tindakan. Pendekatan angket dipandang masih banyak memiliki kelemahan.

Beberapa aliran dari positivistik memandang individu-individu ialah pasif, terjadinya perubahan pada individu disebabkan oleh kekuatan-kekuatan sosial di luar dirinya. Namun berbeda halnya dengan pendekatan interaksionisme simbolik memandang bahwa manusia jauh dari nilai pasif, yaitu aktif (Mulyana dan Rakhmat, 2006: 155). Interaksionisme simbolik adalah teori yang dipengaruhi oleh kekuatan 'diri' (self) dan keinginan (mind) (Mead, 1934; lihat hingga ke definisi Charles Horton Cooley dalam Mulyana dan Rakhmat 2006 155). Mead, sama halnya Cooley, menganggap bahwa konsep diri adalah suatu proses yang berasal dari interaksi sosial individu dengan orang lain (Mulyana dalam Heryadi dan Silvana 2013: 101). Sementara Mind adalah respon diri sendiri yang mempengaruhi sikap dan tindakan pikirannya.

Berdasarkan penjelasan di atas, penulis melakukan metode kerja kualitatif dengan melakukan pengamatan terhadap beberapa mahasiswa Fakultas Adab dan Ilmu Budaya UIN-SUKA. Di samping mengamati informen, penulis juga melakukan percakapan tidak formal: rekan bicara (interlocutor). Hal ini dilakukan untuk mendapatkan data informen secara mendalam. Pendekatan interocutor dilakukan di lingkungan kampus Fakultas Adab dan Ilmu Budaya UIN-SUKA. Penulis menghampiri mereka untuk diajak 'ngobrol' (dialog). Dialog ini dilakukan di lorong- lorong kampus, kantin Fakultas, tempat foto copy, acara Pekan Budaya, lobby Fakultas, dan ruang terbuka hijau. Sementara, informen dalam peneltian ini adalah berjumlah tiga belas orang. Laki-laki tuju orang, dan perempuan enam orang. Mereka terdiri dari semester dua, empat dan enam. Namun dari informen yang penulis hadirkan kebanyakan mahasiswa/I smester dua dan empat. Sedangkan untuk semester enam hanya sebagian kecil, beberapa orang saja. Sedangkan nama informen penulis cantumkan dalam penelitian ini menggunakan nama samaran untuk melindung identitas subjek. Nama -nama tersebut di antaranya sebagi berikut: Dini A (suku Melayu), Winda Mariana Anggi (Bugis), Sutrisno (Jawa), Amanda Putri Larasati (Minang), Sinta Irliyana Caniago (Minang), Dodi (Jawa), Husain (Jawa), Wulandari (Jawa), Lukman, Ujang (Sunda), Enjang (Jawa-Manado), dan Arnol S (Batak). Penelitian ini dilakukan dari mulai tanggal 28 Desember 2018 sampai 07 Februari 2019.

Fakultas Adab dan Ilmu Budaya UIN-SUKA dipilih berdasarkan tempat yang terjangkau dan ada hubungan kenal antara penulis dengan subjek peneliti. Hubungan kenal ini membuat informen lebih terbuka pada peneliti. Sehingga data yang disampaikan oleh informen mendalam.

\section{KERANGKA TEORITIS}

Penulis melakukan pendekatan teori adaptasi budaya. Adaptasi budaya merupakan proses jangka panjang dalam rangka penyesuaian diri, di mana tahapan akhir dalam proses ini adalah tercapainya perasaan nyaman dalam lingkungan yang baru (Kim dalam Martin dan Nakayama, 2000: 277). Seseorang yang hidup di lingkungan baru mereka kenal mempunyai tantangan yang beragam, baik secara bahasa, sikap masyarakat, sistem kepercayaan serta budaya yang berbeda dengan lingkungan sebelumnya.

Selanjutnya, dalam kerangka teoretis ini penulis menggunakan teori akulturasi. Akulturasi sebagai proses melakukan penyesuaian diri warga pendatang dengan budaya pribumi (Astuti 2014: 311). Menurut Kim, proses akulturasi akan mulai berlangsung apabila seorang imigran memasuki budaya pribumi. Proses ini akan terus berlangsung selama imigran mengadakan 
kontak langsung dengan sistem sosio-budaya pribumi (Martin dan Nakayama, 2000: 277).

Dari kedua teori di atas penulis gunakan untuk membahas temuan penelitian ini. Kemudian, pada bagian hasil dan pembahasan dalam artikel ini penulis akan mendiskusikan temuan-temuan hasil penelitian dengan teori-teori komunikasi antarbudaya dan penelitian sebelumnya. Sehingga akan berkontribusi pada kajian komunikasi antarbudaya etnis lokal dengan etnis pendatang pada mahasiswa.

\section{HASIL DAN PEMBAHASAN}

Manusia adalah mahluk yang paling sempurna diciptakan oleh tuhan. Manusia memiliki akal, emosi, dan nafsu. Dalam kajian ilmu sosiologi, Menurut Muslim (dalam Al-Munawir, 1993) manusia adalah mahluk sosial dan budaya. Sebagai makhluk sosial dan budaya, manusia akan terus berkembang, membentuk kebudayaan dan peradaban baru. Untuk mewujudkan citacita itu, manusia harus melakukan kerjasama. Dalam perjalannya waktu, manusia sering dihadapkan pada berbagai fenomena dan polemik hidup yang terkadang membuat mereka harus keluar dari wilayahnya. Kemudian mereka memilih pergi ke daerah lain untuk mendapatkan masa depan yang lebih cerah. Bertemu dengan orang baru, budaya baru dan lingkungan sosial baru. Itu adalah gambaran dari kisah cerita kehidupan para mahasiswa yang melakukan studi ke luar daerah.

Setiap tahunnya perguruan tinggi Islam diseluruh Indonesia selalu menerima mahasiswa baru, salah satunya di antaranya adalah UIN-SUKA. UIN-SUKA dikenal sebagai salah satu kampus yang menjunjung tinggi budaya Jawa dan sikap toleransi yang tinggi antar sesama mahasiswa. Di samping itu, UIN-SUKA juga dikenal sebagai kampus yang terbuka dengan berbagai latarbelakang, agama, etnis, dan budaya, maka tidak heran jika setiap tahunya jumlah calon mahasiswa yang mendaftarkan diri ke kampus UIN-SUKA selalu mengalami kenaikan secara signifikan.

Dari data media massa online Radarjogja.com mencatat pada tahun 2019 calon mahasiswa baru yang mendaftar di UIN-SUKA berjumlah 22.840. Jumlah ini meningkat $31 \%$ dari tahun 2018 lalu yaitu 17.446 (diakses pada tanggal 07 September
2019). Sedangkan untuk jalur Mandiri saja, calon mahasiswa baru yang mendaftar ke UIN-SUKA di tahun 2019 ini mencapai 8.195 dari 844 kursi yang diperebutkan (Detik.com/news, diakses tanggal 07 September 2019). Berdasarkan data tersebut, ikhwal ini menunjukan bahwa minat calon mahasiswa baru yang ingin studi ke kampus UIN-SUKA mengalami kenaikan cukup signifikan. Sementara, kuota yang diterima hanya 3.860 orang (uin-suka.ac.id). Selanjutnya, para mahasiswa baru yang diterima di kampus UIN-SUKA tidak hanya berasal dari pulau Jawa, namun juga berasal dari berbagai pulau di luar Jawa (data diambil dari bidang akademik UIN-SUKA). Seperti pulau Sumatera, Kalimantan, Sulawesi, Lombok, Nusa Tenggara Timur dan masih banyak lainnya. Dari berbagai latarbelakang etnis budaya ini membuat kehidupan kampus UINSUKA semakin dinamis.

Menelisik tentang komunikasi antarbudaya, para mahasiswa baru yang diterima di UIN-SUKA harus menyesuaikan diri dengan lingkungan kampus. Aturan-aturan yang telah ditetapkan harus dipatuhi oleh mahasiswa baru. Tidak hanya itu, mereka juga harus terbiasa dengan budaya Jawa yang sudah mengakar di kampus UIN-SUKA. Berbagai kondisi seperti ini, mau atau tidak mereka harus berbaur, berinteraksi, dan beradaptasi dengan lingkungan baru. Begitu juga dengan mahasiswa lokal, mereka harus memberikan ruang kepada mahasiswa luar Jawa untuk membuka diri dan membuatnya merasa nyaman.

Mahasiswa Fakultas Adab dan Ilmu Budaya di UIN-SUKA terdiri dari berbagai etnis dan budaya. Etnis Jawa mendominasi suku yang ada di Fakultas Adab dan Ilmu Budaya UIN-SUKA. Misalnya dalam setiap pertemuan, bahasa Jawa sering digunakan dalam diskusi di kelas-kelas, tempat duduk, lorong-lorong, kantin dan pelataran fakultas. Namun, tidak banyak dari teman -teman mereka memahami bahasa Jawa, karena mereka bukan berasal dari suku Jawa dan daerah Jawa. Dalam posisi seperti ini mereka harus beradaptasi dengan teman-teman etnis lokal, agar mereka tidak teraliniasi oleh lingkuangan baru.

Menurut Heryadi dan Silvana (2013: 97) adaptasi merupakan penyesuaian diri kelompok pendatang ke masyarakat lokal sebagai upaya penyesuaian diri. 
Adaptasi membutuhkan proses resosialisasi antara budaya lama dengan budaya baru. Interkasi yang dilakukan secara terus menerus oleh manusia akan mengubah pandangan kebiasaan sebelunya. Seperti mengadopsi nilai-nilai dan norma-norma baru dari budaya lokal Heryadi dan Silvana (2013: 97).

Selengkapnya percakapan di antara mereka sebagai berikut:

"Saya kan baru di sini dan bukan suku asli Jawa. Jadi, kalau saya ditanya pakai bahasa Jawa ya gak paham. Apalagi bahasanya sangat jarang saya dengar, kalau cuma kepripun kabare, ajeng ngertos, empun maem nopo dereng ya saya tau. Tapi kalau ditanya yang gak pernah saya dengar (asing) ya, saya gak paham gitu! Paling ya senyum-senyum aja, sambil bengong gitu, tapi kalau ditanya seperti itu gak papa juga sih, jadikan saya bisa belajar lebih banyak bahasa Jawa. Kumpul dengan orang-orang Jawa juga kan baik, asyik dapat teman baru. Jadi saya bisa berteman dengan orang Jawa, banyak hal yang bisa diambil dari budaya mereka (Dini mahasiswa suku Melayu, responden 1, data intelekutor diambil pada tanggal 01 Januari 2019)."

"Saya juga kalau ditanya bahasa Jawa tidak nyambung Daeng, karena saya kan orang bugis. Dari logat saja udah beda, dialek kamikan intonasinya keras ya tegas gitu, kalau Jawa kan beda, lembut gitu, ramah. Kalau saya sedang ngobrol-ngobrol sama temen-temen beda suku pasti pakai bahasa Indonesia, tapi kadang orang Jawa bilangnya pakai bahasa Jawa sama Iya', jadikan Iya' gak nyambung gitu. Ya kalau bahasa yang receh-receh seperti kue mangan urung? atau kue arep nengendi? kaya gitu paham daeng. Tapi kalau nanyanya baru iya' dengar Iya' Ki...! gak paham. Pertama, karena mereka ngomongnya agak pelanpelan, terus. Jadi apa yang diucapkan temanteman saya samar-samar gitu. Mau gimana ya, tapi kadang itu bagus, jadinya saya bisa banyak belajar bahasa Jawa dengan teman-teman saya orang Jawa. Kalau saya gak paham, saya minta artikan, kadang saya juga senyumsenyum sok tau gitu, nyambung, padahal tidak tau apa yang teman-teman Jawa bicarakan. Ya gitulah mas, butuh belajar dan nyesuaikan sama lingkungan sekitar (Winda, responden ke -2, data diambil pada tanggal 31 Desember 2018)."

Dari pernyataan di atas, dapat dipahami bahwa para mahasiswa luar Jawa mengaku tidak memahami perkataan yang disampaikan oleh teman mereka etnis Jawa. Mereka merasa kesusahan dalam memahai makna yang disampaikan oleh teman mereka ketika berbicara bahasa Jawa. Hal ini membuat komunikasi sesama mereka tidak berjalan secara efektif. Untuk mencegah ketidakefektifan komunikasi antar mereka, suku Jawa mencoba menambahkan gerak-gerik tubuh yang berisi makna simbol, simbol-simbol itu dipraktekkan bersamaan dengan kata-kata yang akan diucapkan. Walaupun terlihat rumit tapi cara ini dapat membantu teman mereka yang tidak mengerti bahasa Jawa. Pada posisis seperti ini, teori interaksi simbolik sangat berperan. Teori interaksi simbolik memusatkan perhatian pada tanda-tanda yang menjelaskan tentang isi penjelasan subjek kepada lawan bicara (komunikan). Maka konsep 'tindakan' di sini sangat penting untuk memahami sikologis manusia. Yaitu bagaimana komunikator memahami apa yang menjadi hambatan seorang komunikan sebagai teman bicaranya.

Sejalan dengan apa yang disampaikan oleh Herdi dan Silvana (2013), tindakan dipandang sebagai tingkah laku yang dibentuk oleh pelaku untuk memahani objek, yaitu manusia. Karena menurut Meat (1934) manusia dipandang sebagai organisme aktif yang memiliki hak-hak terhadap penjelasan orang lain (lihat juga Heryadi dan Silvana, 2013). Di samping itu, interaksi sosial menjadi bagian penting dari hidup manusia untuk menjalin relasi antas manusia. Interaksi sosial tidak hanya dalam bentuk verbal namun juga non -verbal. Hal ini sejalan dengan pendapat Heryadi dan Silvana (2013) bahwa interaksi tidak hanya dilakukan dalam bentuk kata-kata, akan tetapi juga melalui simbol -simbol secara face to face (Heryadi dan Silvana, 2013). Sementara Fisher (1986: 135) mengatakan hubungan antar manusia dalam proses komunikasi di- 
pengaruhi oleh 'interaksionis' (lihat juga Sikumbang, 2017: 82). Interaksionis ialah tindakan yang menekankan pada tingkah laku individu ke individu lain untuk memahami orang lain sebagaimana memahami dirinya sendiri. Individu dapat dipahami diantaranya melalui interaksi, salah satunya adalah melakukan pertukaran simbol dalam proses komunikasi agar terbentuknya komunikasi yang efektif (Sikumbang, 2017: 82).

Berdasarkan hasil wawancara dengan Siti Sulastri, dan Ahmad Sutresno seorang mahasiswa/I etnis Jawa, mengapa mereka lebih memilih menggunakan bahasa Jawa dari pada bahasa Indonesia, karena mereka ingin mengajarkan kepada teman-teman mereka berbeda suku agar bisa berbahasa Jawa. Mereka mengatakan apabila studi di Yogyakarta tidak bisa bahasa Jawa aneh rasanya bagi mereka.

Selengkapnya hasil cuplikan wawancara penulis dengan Siti Sulastri dan Akhmad Sutresno sebagai berikut:

"Saya kalau sama teman-teman di kampus ya, banyak gunakan bahasa Jawa, nggak ngurus! Itu temen Jawa atau bukan, seperti Sunda, Minang, Makasar atau Bugis. Saya kan orang Jawa. Ya, sekalian saya kenalkan bahasa Jawa ke mereka-teman-teman, biar mereka pada bisa bahasa Jawa, budaya Jawa juga. Biar mereka tau kearifan budaya Jawa di Yogyakarta." (Siti Sulastri, responden 1, data diambil pada tanggal 28 Desember 2018).

“Aku kan orang Jogja, ya wajib toh pakai bahasa Jawa! Lagian orang-orang di sini ngomongnya banyak pakai bahasa Jawa toh. Sekalian lestarikan nilai-nilai budaya lokal Jogja. Lagian, mereka pun juga senang kalau aku ajarkan bahasa Jawa gitu, walaupun kadang mereka gak paham artinya, gak tau, gak nyambung gitu. Tapi lama-kelamaan mereka paham juga nanti. Begitu juga aku, belajar bahasa mereka, biar tau gimana bahasa mereka" (Sutresno, responden 7, data diambil pada tanggal 01 Januari 2019)."

Di sisi lain, mereka juga mengatakan walau- pun mereka tidak memahami bahasa Jawa, tetapi mereka mencoba untuk bergabung, berbaur dengan suku Jawa. Mereka mencoba menjadi pendengar yang baik dan bijak di dalam komunikasi antarbudaya ini. Seperti menekankan pada pengembangan diri agar lebih aktif terhadap lingungan sosial. Hal ini sesuai apa yang dikatakan oleh Salmaniah (2011: 104) bahwa interaksi simbolik berfokus konsep diri (self-concept) di mana individu bertindak secara aktif, mengembangkan konsep diri yang didasarkan pada interaksi sosial dengan orang lain. Seperti penulis hadirkan dalam percakapan hasil interlokutor dengan salah satu informen sebagai berikut ini:

"Bagi saya sendiri sulit untuk memahami bahasa Jawa, apalagi saya orang Minang, jarang mendengar bahasa Jawa. Ya, kalau pun saya tidak tau apa maksud! ucapan teman-teman orang Jawa itu, tapi saya akan coba untuk dengarkan bahasa mereka, memahai apa yang mereka sampaikan. Karena saya hidup di lingkungan Jawa. ya harus bisa menyesuaikan dong dengan lingkungan sekitar. Bagi saya bicara sama mereka memiliki sisi positif, dari situ bisa belajar banyak tentang bahasa Jawa. Ya walaupun sekarang taunya injih, boten tapi semangat untuk belajar bahasa Jawa saya sangat kuat. Suatu saat saya nanti akan bisa berbahasa Jawa (Amanda Putri Larasati, responden 3, data interlokutor diambil pada tanggal 29 Desember 2018)."

Di dalam komunikasi antarbudaya, setiap masyarakat memiliki kebudayaan yang berbeda-beda dari budaya satu dengan budaya lainnya. Masyarakat yang menginginkan perubahan sosial sudah seharusnya membuka diri terhadap budaya lain. Ini disebut sebagai proses adaptasi (Heryadi dan Silvana, 2013:96). Kondisi di sekitar kita yang menyebabkan komunikasi antarbudaya dirasakan semakin penting pada saat ini, di antaranya karena adanya mobilitas manusia (De Vito, 1997: 475-477).

Sesuai dengan teori di atas, bahwa mahasiswa Fakultas Adab dan Ilmu Budaya UIN-SUKA melakukan tindakan yang sama untuk membuka diri dan berbaur dengan teman-temannya yang memiliki 
kebudayaan berbeda. Kemudian, dengan adanya lingkungan baru mereka menginginkan perubahan sosial dari kehidupan yang sebelumnya. Dari kehidupan satu budaya ke kehidupan berbeda budaya. Pentingnya bagi mereka untuk menyesuaikan diri dari temannya yang berbeda kebudayaan agar kehadirannya diterima.

Saat mereka ditannya dengan bahasa Jawa, mereka hanya mengangguk-angguk seolah-olah paham. Padahal mereka tidak mengetahui apa yang dimaksud oleh temannya, mereka sambil tertawa. Mereka 'bingung dan tidak paham.' Untuk membuat mereka paham tentang apa yang dimaksud oleh teman-teman mereka, mereka mulai menggunakan simbol dan isyarat -isyarat gerakan tubuh untuk memperjelas apa yang disampaikan oleh temannya mereka.

Seperti hasil dialog responden, sebagai berikut:

"Temanku di Jogja kebanyakan orang Jawa sih. Kalau kita ngumpul bareng gitu pasti banyak gunakan bahasa Jawa, ya.... bahasanya medok-medok gitu! ngapak mungkin ya! He he he. Ada juga pelan-pelan ngomongnya. menurutku sih agak aneh gitu bagiku, mungkin belum biasa, jadinya kan aneh... mungkin karena gak biasa dengering bahasa kaya gitu ya, tapi aku juga senang bisa kumpul dengan mereka, bisa banyak belajar bahasa Jawa jadinya deah. Kadang mereka juga paham kok sama aku, ngerti kalau aku belum bisa bahasa Jawa, gak sedikit juga mereka gunakan bahasa isyarat, tangan dan ekspresi diri. Supaya aku bisa paham maksud mereka ngomong apa. Seperti ekspresi nawarin minum apa Sinta? Kita mau makan apa sekarang? Aku merasa senang karena mereka perhatian sama aku. Namun ada juga dari mereka sedikit nyebelin, tapi mereka bercanda! Orang Jawakan banyak bercandanya." (Sinta informen 4, data intelokutor diambil pada yanggal 06 Februari 2019).

Menurut teori interaksi simbolik, kehidupan sosial pada dasarnya adalah "interaksi manusia dengan menggunakan simbol-simbol” (DeVito, 1997: 475-477; Mulyana dan Rakhmat, 2006: 155). Mereka tertarik pada cara manusia menggunakan simbol-simbol yang mempresentasikan apa yang mereka maksudkan untuk berkomunikasi dengan sesamanya, dan juga dampak yang ditimbulkan oleh penafsiran atas simbol-simbol terhadap perilaku pihak-pihak yang terlibat dalam interaksi sosial. Ini yang dirasakan oleh para mahasiswa yang belum mengetahui bahasa dan budaya Jawa.

Penganut interaksi simbolik berpandangan bahwa perilaku manusia pada dasarnya adalah produk dari interpretasi mereka atas dunia disekeliling mereka, dan tidak mengakui bahwa perilaku itu ditentukan, sebagaimana dianut oleh teori behavioristik atau teori struktural. Dengan kata lain, perilaku dipilih sebagai hal yang layak dilakukan berdasarkan cara individu mendefinisikan situasi yang ada (Mulyana, 2004:71). Asumsi dasar dari teori interaksi simbolik adalah pertama, manusia mampu menciptakan simbol-simbol dan mempergunakannya. Kedua, manusia mempergunakan simbol-simbol tertentu untuk berkomunikasi dengan manusia lain. Ketiga, dengan menginterpretasikan simbol-simbol yang diberikan oleh pihak lain seorang individu akan berperilaku tertentu sebagai tanggapan terhadap adanya simbol yang diterima (Zamroni, 1998: 55). Sementara, Deddy Mulyana (2014: 131) mengatakan simbol (nonverbal) merupakan cara yang tepat untuk menjelaskan sesuatu berdasarkan kesepakatan bersama. Dalam hal perkataan, kemungkinan orang yang diajak bicara tidak bisa memahami gagasan yang disampaikan oleh orang lain, maka dibutuhkan simbol untuk mengikat makna yang dimaksudkan oleh komunikator.

Setelah melakukan tahapan, proses demi proses, seiring dengan berjalanan waktu mereka mulai memahami bahasa teman-teman mereka (Jawa). Kemudian, tidak sediki dari etnis Jawa mulai mencoba mempelajari bahasa di luar dari bahasa mereka. Sebut saja Bugis, Toraja, Madura, Sunda, Batak, Minang dan lainnya. Mereka juga mengalami kesusahan ketika dialog dengan bahasa yang bukan dari bahasa ibu mereka sendiri. Seperti yang dikatakan di bawah ini.

Suka juga kalau kumpul dengan teman-teman yang bukan dari orang Jawa. Jadi aku bisa belajar kepribadian mereka. Seperti apa orangnya, sifatnya dan kepribadiannya. Terus 
budayanya gimana. Gimana kalau dia temanteman ku suku Sunda ngomong bahasa Sunda. Ya walaupun kurang tau apa artinya, tapi lama kelamaan nanti ngerti juga. Lagian bagus juga kalau kita banyak tau tentang bahasa daerah orang lain. Seperti teman-temanku orang Batak, terdengar keras dan marah-marah, tapi sebenarnya dia gak marah. Gitu juga dengan temenku yang suku Bugis, kemudian Toraja mendayu-dayu, beda lagi dengan Minang yang cepat ngimongnya (Nuril Anwar $S$, responden 5, data diambil pada tanggal 03, dan 09 Januari 2019).

"Saya kan Jawa orangnya mas, Solo lagi. Pasti nadanya pun beda dengan orang Sumatera. Kalau Jawakan lembut gitu ya, kalau Minang kan agak keras, apalagi Batak, bicaranya keras -keras, ngebu-ngebu gitu, seperti orang marah gitu. Tapi sebenarnya mereka nggak marah, mungkin kita juga bisa belajar bahasa mereka. Seperti temanku yang orang minang itu, dan Batak. Walaupun suaranya nyaring keluar tapi mereka asik kok untuk buat teman. Pingin bisa juga sih rasanya belajar bahasa mereka, kan bagus tuh untuk menambah pengetahuan, kosa kata. Kita juga gak tau suatu saat pergi ke Sumatera." (Wulandari responden 6, data diambil pada tanggal 05, 16 Januari 2018).

Namun, sesuai dengan waktu yang berjalan mereka mulai bisa dan memahami bahasa di luar bahasa Jawa, sebut saja Melayu, Minang, Bugis, Sunda, Batak, madura dan lainnya. Sehingga komunikasi antarbudaya mahasiswa Adab dan Ilmu Budaya ini mencair. Pentingnya bagi mereka untuk mempelajari bahasa di luar dari bahasa ibu mereka adalah untuk memperkaya wawasan mereka tentang bahasa-bahasa yang ada di luar Jawa. Sikap saling menghargai antar etnis ini setidaknya diperlihatkan dengan kesediaan suku Jawa untuk mempelajari bahasa dari etnis lain. Seperti hasil wacancara di bawah ini:

"Kalau menurutku bergaul sama teman-teman selain orang Jawa juga menyenangkan, banyak keuntungannya kok! Salah satunya, saya bisa banyak belajar bahasa daerah mereka, seperti
Melayu, Minang, Batak atau Bugis gitu. Kita juga kan gak tau sih! kalau bakalan suatu saat pergi ke daerah mereka. Ketika pergi ke sana, kalau tau bahasa mereka kan enak. Ngobrolngobrol gitu sama warga sana. Lagian mereka juga asik buat dijadikan teman, dengan budaya yang berbeda bisa banyak belajar memahai karakter teman-teman." (Husen, responden 8, data intelokutor diambil pada tanggal 31 Desember 2018, 01 Januari 2019).

Keharmonisan dalam komunikasi antarbudaya juga dipengaruhi oleh keefektifan komunikasi yang dilakukan oleh para pelaku komunikasi tersebut. Suatu komunikasi dinilai efektif bila rangsangan yang disampaikan oleh pengirim sumber informasi berkaitan erat dengan rangsangan yang ditangkap dan dipahami oleh penerima pesan tersebut. Intinya antara sender (S) dan receiver $(\mathrm{R})$ ada kesamaan dalam memahami makna pasan yang telah disampaikan (Amaliya, 2017: 28)."

Kemudian, dalam setiap budaya dan bahasa yang berbeda-beda pasti menimbulkan sikap dan perilaku yang berbeda juga. Misalnya para mahasiswa Adab dan Ilmu Budaya UIN-SUKA beretnis Batak memiliki sikap yang keras, lantang, tegas, dan terbuka. Berbeda dengan etnis Jawa dari Surakarta atau Yogyakarta yang memiliki ucapan lembut dan beretika santun. Perbedaan seperti ini sudah disikapi sejak lama. Sebagai bangsa yang manjemuk, perbedaan-perbedaan terhadap suku, etnis, ras, budaya dan agama dapat diterima dengan baik. Perbedaan tersebut sebagai keniscayaan yang harus disikapi dengan bijak, agar tidak terjadinya gangguan komunikasi antar mereka. Terutama bagi mereka yang berasal dari luar Jawa. Sumatera, Kalimantan, Sulawesi dan lainnya.

Dengan demikian, tidak sedikit dari mereka melakukan penyesuai diri terhadap sikap dan prilaku teman-teman yang berbeda kebudayaan. Ada yang malu-malu, cari perhatian, dan sedikit cuek. Maka disini perlunya hubungan yang intensif antar sesama mereka dalam pendekatan komunikasi antarbudaya. Menurut Koentjaraningrat (1993) budaya minoritas dipengaruhi oleh budya mayoritas sebagai akibat dari tekanan lingkungan. Dengan kata lain, etnis minoritas akan menyesuaikan diri terhadap budaya mayoritas. 
Pada akhirnya etnis minoritas akan menyelaraskan berdasarkan konteks lokal. Di samping itu, batas antar budaya dapat dipertahankan meski ke duanya berbaur. Sehingga perbedaan identitas etnis dapat dipertahankan dalam pergaulan.

Menyadari berbagai perbedaan tersebut, membuat mereka saling memahami latarbelakang, karakter dan kepribadian antar mereka. Sudah seharusnya mereka melakukan penyesuai diri, belajar dan mengenal karakter dari setiap teman-teman mereka. Maka pentingnya bagi mereka untuk melakukan komunikasi antarbudaya. Dengan demikian, mereka semakin dewasa untuk menyikapi perbedaan budaya di antara mereka dan lebih jauh lagi mereka dapat memperkuat hubungan solidaritas antarbudaya.

Seperti dalam cuplikan hasil wawancara di bawah ini:

"Memang asyik saya kuliah di sini atuh Aa. Bisa ngenal banyak orang! Dari latarbelakang mereka yang beda-beda. Jadi saya seneng pisan bisa kuliah di UIN sini, jadi abdi banyak belajar budaya orang lain di sini. Misalnya mengenal suku Jawa, Makasar, Bugis, Toraja, Madura dan banyak lainnya. Pikiran urang kabuka." (Ujang, responden 10, data wawancara diambil pada tanggal 18 Januari 2019).

"saya juga bisa lebih mengenal budaya mereka secara mendalam, gimana sikap mereka, sifat dan kebiasaan. Ya pokoknya banyak belajar budaya orang lain buat saya lebih dewasa dan bijak dalam menyikapi perbedaaan dan permasalahan juga. Kaya masalah ucapan yang tidak enak kan, menyinggung hati, sikapnya yang gak lembut dan ......" (Enjang, responden 11, data wawancara diambil pada tanggal 26 Januari 2019).

"Saya kan baru pertama kali hidup di Jawa, sebelumnya kan belum pernah. Jadi harus nyesuaikan dulu dengan teman-teman baru di sini. Bagi saya, sebagai orang Batak banyak teman itu kan enak, memperkaya wawasan juga pertemanan. Lagian ingin tau bagaimana budaya Jawa-Sunda di sini. Orang Jawa yang lebut-lembut, baik-baik, sopan-sopan." (Arnol $S$, responden 13, data wawancara diabil pada tanggal 27 Januari 2019).

"Saya juga memahami bagaimana tementemen saya ada yang berasal dari luar Jawa. Saya buat wellcome, orang Papua juga saya wellcome, walaupun kadang persepsi temanteman saya di Fakultas lain banyak yang menjauhi mereka. Saya bilang ke teman saya jangan gitu lah, kita saudara, satu tanah air. Jadik kalau saya gak ada tuh pilih-pilih teman. Kalau pilih-pilih teman itu namanya egois, dan gak terbuka sama orang lain. Kita kan satu perjuangan, lagian sebaik-baik orang kan yang paling bertakwa. Ya kan! . saya juga berharap mereka teman-teman saya yang beda suku merasa nyaman di sini, seperti kampung mereka sendiri." (Sutresno, Responden 7, data wawancara diambil pada tanggal 03 Februari 2019).

Seseorang yang hidup di lingkungan baru yang baru dia kenal mempunyai tantangan yang beragam. Baik secara bahasa, sikap teman-teman, sistem kepercayaan serta budaya yang sangat berbeda dengan lingkungan sebelumnya. Untuk beradaptasi dan dapat hidup di lingkungan yang beragam etnis dan budaya, para komunitas dituntut untuk menghargai budaya antar mahasiswa. Adaptasi budaya merupakan proses jangka panjang dalam rangka penyesuaian diri di mana tahapan akhir dalam proses ini adalah tercapainya perasaan nyaman dalam lingkungan yang baru (Kim dalam Martin dan Nakayama, 2000: 277).

Adaptasi budaya dapat terjadi misalnya pada mahasiswa yang mengikuti program pertukaran pelajar internasional, diplomat, misionaris, ataupun tentara perdamaian. Selain itu adaptasi budaya dapat pula terjadi pada imigran atau pengungsi yang berpindah dari suatu tempat ke tempat yang sama sekali baru. Juga berlaku bagi seseorang yang secara individual berimigrasi dari pelosok pedesaan pindah ke ke kota yang metropolitan (Gudykunst dan Kim, 1992: 214). Dari sini, manusia memperoleh aturan-aturan komunikasi melalui tiga proses, yaitu: internalisasi, kulturasi 
dan akulturasi (Rumondor, 2005: 40).

Bagi para mahasiswa imigran yang datang ke pulau Jawa mereka harus menyesuaikan diri dengan kondisi lingkungan yang ada. Mereka harus tetap menjaga kelangsungan hidupnya serta senantiasa menjadi bagian dari mahasiswa lokal. Bersentuhan dengan budaya yang sama sekali masih baru merupakan situasi yang tidak dapat dihindari oleh para mahasiswa pendatang. Dalam keadaan seperti itu, mereka akan lebih banyak mengenal berbagai macam kebudayaan yang baru. Sehingga mereka lebih terbuka dan toleransi kepada orang-orang baru. Dengan demikian, Komunikasi antarbudaya membuat mereka saling mengenal, terbuka, memahami dan toleransi antar mahasiswa.

Kesadaran mereka tentang keberagaman kebudayaan ini menghasilkan sebuah negosiasi dalam kebudayaan di mana mereka saling mengenal budaya satu dengan yang lainnya untuk dipelajari, dipahami dan dipraktekan pada teman-teman mereka yang berbeda budaya. Dalam setiap acara atau pertunjukan misalnya, mereka sering melakukan kolaborasi antarbudaya satu dengan yang lainnya. Seperti pada acara Pekan Budaya Fakultas Adab dan Ilmu Budaya UINSUKA. Mereka mengajak ke teman-temannya untuk berpartisipasi ke dalam acara tersebut. Tidak hanya sampai di situ, lebih jauh, mereka melakukan kolaborasi budaya, dari satu budaya ke budaya lainnya atau yang sering disebut juga sebagai akulturasi budaya. Misalnya dalam satu tarian, musik atau drama dikolaborasikan ke dalam beberapa budaya lain.

Seperti kelompok mahasiswa lintas suku mempersembahkan tarian Tor-Tor diiringi dengan musik Gamelan. Begitu juga tarian Jaepong Sunda dengan musik Jawa yang dikolaborasikan dalam satu penampilan. Dari kombinasi tersebut menghasilkan ritma baru yang menarik. Sehingga memberikan kesaan positif bagi penonton. Kemudian, budaya-budaya daerah lain juga meraka kolaborasikan dengan budaya lokal. Seperti tari Saman Aceh berkolaborasikan dengan tarian Paduppa Bosara, Minang dengan Jawa. Kemudian, perpaduan musik langgam Jawa dengan Arab (gambus), atau drama lokal-berjendre India, begitu juga budya popular dengan Jawa. Semuanya saling mengisi satu sama lain dan memberikan warna segar dinamika budaya mahasiswa Fakultas Adab dan Ilmu Budaya UIN-SUKA.

Selengkapnya dapat disimak dalam percakapan wawancara penulis dengan informen sebagai berikut ini:

"Ketika fakultas ngadain acara pegelaran budaya, aku dan teman-teman selalu menyambut acara itu dengan senang. Di sini kami melakukan kolaborasi seni budaya, seperti tarian, musik, drama, dan pementasan musik tradisional. Teman-teman juga kalau aku ajak mereka pada mau kok. Karena teman-teman bilang ini ide-ide yang bagus. Jadi kita tampil dengan cara yang gak biasa." (Winda responden 2 dibeanrkan oleh Sutresno (res. 7) dan Sinta (res. 4), data diambil pada tanggal 10 Januari 2019).

"Ya suka sih... kita tampil dengan cara yang beda, adanya penyatuan budaya gitu looooh.... seperti Jawa dan Sunda, kemudian Minang dengan Jawa, bisa juga dari India misalnya atau Turki dengan Jawa." (Wulandari, responden 6, data diambil pada tanggal 02,03 Januari 2019).

Di dalam ilmu sosial, dapat dipahami bahwa akulturasi merupakan proses pertemuan unsur-unsur kebudayaan yang berbeda, kemudian bercampur menjadi satu, namun perbedaan di antara unsur-unsur asing dengan yang asli masih tampak. Lebih lanjut, akulturasi merupakan suatu proses di mana warga pendatang melakukan penyesuaian diri dengan budaya pribumi (Astuti 2014: 311). Menurut Heryadi dan Silvana (2013: 103) akulturasi sebagai suatu proses di mana para individu atau warga suatu masyarakat dihadapkan dengan pengaruh kebudayaan lain dan asing.

Dalam proses itu sebagian mengambil alih secara selektif sedikit atau banyak unsur kebudayaan asing, dan sebagian berusaha menolak pengaruh itu. Kultur yang telah terbentuk sebelumnya dapat berubah ketika mendapat pengaruh dari budaya luar melalui proses akulturasi. Menurut Kim (dalam Marin dan Nakayama, 2000: 277), proses akulturasi akan mulai berlangsung apabila seorang imigran memasuki ke dalam budaya pribumi (lokal). Proses ini akan terus berlang- 
sung selama imigran mengadakan kontak langsung dengan sistem sosio-budaya pribumi.

Berbagai penjelasan di atas, mahasiswa Fakultas Adab dan Budaya mampu membangun hubungan yang baik antar sesama mereka, walau pun berbeda budaya. Melalui proses interaksi sosial, penyesuaian diri, adaptasi, akulturasi budaya dan proses interaksionalisme simbolik mereka dapat menyatu dari berbagai perbedaan, latarbelakang budaya, kesenjangan, dan lingkungan baru disekelilingnya. Namun dari kasus yang terjadi pada mahasiswa/I Fakultas Adab dan Ilmu Budaya tidak dinafikan juga terdapat gesekan dan konflik sosial, akan tetapi itu hanya sebagaian kecil dan tidak menjadi permasalahan yang begitu besar. Karena disebabkan oleh latarbelakang pendidikan mereka, dari disiplin ilmu budaya. Berdasarkan telisikan penulis, perbedaan pandangan antara sesama mereka dapat mereka disikapi secara bijak. Hal ini berdasarkan hasil 'wawancara' dan pendekatan 'interlokutor' penulis dengan informen, bahwa tidak ada ditemukan permasalahan besar di antara mereka yang menyebabkan terjadinya konflik sosial. Di samping itu, dalam artikel ini, penulis juga tidak fokus pada pembahasan konflik sosial komunikasi anarbudaya mahasiswa/I. Penulis hanya ingin menelisik atau menjelaskan bagaimana komunikasi antarbudaya etnis lokal dengan etnis pendatang dilakukan, dengan mengkaji studi pada mahasiswa/I Fakultas Adab dan Ilmu Budaya UIN-SUKA.

\section{PENUTUP}

Berdasarkan hasil penjelasan penelitan di atas, dapat disimpulkan bahwa komunikasi antarbudaya mahasiswa/I Fakultas Adab dan Ilmu Budaya berlangsung secara baik, walaupun pada awalnya ada hambatan bagi mahasiswa non etnis Jawa untuk melakukan penyesuaian diri dengan etnis lokal. Hambatan komunikasi antarbudaya tidak lantas menghalangi mereka untuk saling mengenal, mempelajari, beradaptasi, dan mengakulturasikan antarbudaya sesama mereka. Seiring dengan perjalanan waktu, mereka non etnis lokal dapat menyesuaikan diri dengan lingkungan baru teman-teman mereka etnis lokal. Begitu juga sebaliknya, mahasiswa etnis lokal membuka diri terhadap etnis pendatang. Sebut saja etnis Bugis, Toraja, Madura, Sunda, Batak, Minang dan lainnya. Tidak hanya itu, etnis lokal banyak belajar tentang budaya luar. Misalnya, percakapan kehidupan sehari-hari, 'ngobrol,' ngerjakan tugas, diskusi kampus, pegelaran budaya Fakultas dan lain-lain. Pada akhirnya mereka menyatu dalam bingkai akulturasi budaya.

Dari penelitian ini, penulis merekomendasikan ke penelitian yang akan datang pentingnya untuk mengkaji secara khusus penelitian tentang konflik sosial komunikasi antarbudaya antar mahasiswa. Studi ini penting untuk dilakukan karena untuk mememahai bagaimana konflik sosial antar mahasiswa itu terjadi dan bagaimana mahasiswa menyikapi problem itu. Seperti beberapa kasus terakhir ini konflik sosial antar mahaiswa di Surabaya dan Yogyakarta menyita banyak perhatian publik di mana media massa maupun online membanjiri pemberitaan ini.

\section{DAFTAR PUSTAKA}

Arbi, Armawati Arbi. 2003. Dakwah dan Komunikasi. Jakarta: UIN Perss.

DeVito, Joseph A. 1997. Komunikasi AntarManusia.

Edisi ke Lima. Terj. Agus Maulana. Jakarta: Professional Books.

Fisher, B Aubrey. 1986. "Teori-Teoori Komunikasi." Dalam Jalaludin Rakhmad (Penyunting). Bandung: Ramadja Karya.

Gudykunst, W. B. dan Kim, Y. Y. 1992. Communicating with Stangers (an Approach to Intercultural Communication). New York: Mc-Graw Hill Inc.

Heryadi, Hedi dan Hana Silvana. 2013. Komunikasi Antar Budaya dalam Masyarakat Multikultural. Kajian Komunikasi. Volume 1. Nomor 1.

Koentjaraningrat. 1993. Masalah Kesukubangsaan dan Integrasi Nasional. Jakarta: Penerbit Universitas Indonesia.

Martin, N. Judith, dan Nakayama, K. T. (2000). Intercultural Communication in Contexts. New York: Mc. Graw Hill.

Mulyana, D. 2000. Ilmu Komunikasi Suatu Pengantar. Bandung: Remaja Rosdakarya. 2004. Metodologi Penelitian Kualitatif. Bandung: Remaja Rosdakarya. 
2014. Ilmu Komunikasi Suatu Pengan-

tar. Jakarta: Remaja Rosdakarya.

Mulyana, Deddy dan Jalaluddin Rakhmat. 2006. Komunikasi Antarbudaya: Panduan Berkomunikasi dengan Orang-Orang Berbeda Budaya. Bandung: Remaja Rosdakarya.

Rumondor, A. H. 2005. Komunikasi Antarbudaya. Jakarta: Pusat Penerbitan Universitas Terbuka.

Rusdiyanta, Syahrial Syarbaini. 2009. Dasar-Dasar Sosiologi. Jakarta: Graha Ilmu.

Sudjarwo. 2001. Metodeologi Penelitian Sosial. Bandung: Mandar Maju.

Zamroni. 1998. Pengantar Pengembangan Teori Sosial. Malang: Universitas Negeri Malang Perss.

Amaliya, Nur Adli. 2017. "Komunikasi Antar Budaya: Studi Pada Penduduk Urban dengan Penduduk Asli Keluarga Menanggal Kecamatan Gayungan Kota Surabaya." Skripsi. UIN Sunan Ampel Surabaya, Surabaya.

Beatrix, Beatrix dan Pinckey Triputra. 2018. "Tahapan Geger Budaya yang dialami Mahasiswa Indonesia: Studi Kasus Mahasiswa Aktif South China Normal Uniersity." Koneksi. Vol. 1. No. 2. 259-265.

Fitri, Nisa Zuliana, Adnan Madjid, dkk. "Resolusi Konflik Pada Tindakan Kekerasan Terhadap Jemaat Ibadah RosariO di Kabupaten Seleman Daerah Istimewa Yogyakarta.” Jurnal Bina Adhyaksa. Vol. 6. No. 2.

Bahari, Yohanes. "Model Komunikasi Lintas Budaya dalam Resolusi Konflik Berbasis Pranata Adat Melayu dan Madura di Kalimantan Barat.” Vol. 6. No.1. 1-12.

Ghozali Elvina dan Turnomo Rahardjo. 2019. "Adaptasi Komunikasi Antara Strenger dan Host Culture di Kota Medan.” Interaksi Online. Vol. 7. No. 3. 43-52.

Hernawan, Hawan. 2010. "Komunikasi Antarumat Berbeda Beragama: Studi Kasus Sikap Sosial dalam Keragamaan Beragama di Kecamatan Cigugur Kabupaten Jawa Barat. Jurnal Kom dan Realistas Sosial. Vol. 1. No. 1. 62-74.

Heryadi Hendi dan Hanan Silvana. 2013. "Komunikasi Antarbudaya dalam Masyarakat Multikultural. Jurnal Kajian Komunikasi.” Vol. 1. No. 1. 95-108.

Lubis, Lusiana Andriani. 2012. “Komunikasi Antarbudaya Tionghoa dan Pribumi dalam Penggunaan Bahasa." Jurnal Ilmu Komunikasi. Vol. 10. No. 13. 285-294.
2012. "Komunikasi Antarbudaya

Tionghoa dan Pribumi di Kota Medan. " Jurnal Ilmu Komunikasi. Vol. 10. No. 13-27.

Merawa, Asfiah Endang Kasim. 2016. “Kecemasan Komunikasi dalam Relasi Etnis: Studi Pada Mahasiswa Etnis Papua di Unoversitas Halu Oleo.” Journal Ilmu Komunikasi Uho. Vol. 1. No. 1.

Salmaniah, Nina Siti. 2011. "Kajian Tentang Interaksionalisme Simbolik. Perspektif." Vol. 4. No. 2. 100-110.

Sikumbang, Ahmad Tiamrin. 2017. "Teori Komunikasi: Pendekatan, Kerangka, dan Perspektif.” Analytica Islamic. Vol. 6. No. 1. 77-84.

Sjofjan, Kezia Natalia dan Suzy Sazeharie. 2018. "Studi Komunikasi Budaya di Kota Padang: Alkuturasi Budaya Minangkabau pada Etnis Tionghoa di Kota Padang." Vol. 2. No. 2. 409-416.

Umam, Akmad Hairul. "Cross Cultural Adaptation dan Communication Behavior Regional Student of Tantri Abeng University."_Progressive Journal. Vol. 13. No. 1. 43-48.

Yahya, Nurul Athira dan Turnomo Rahardjo. 2018. "Negosiasi Identitas Mahasiswa Papua dengan Host Culture di Kota Semarang." Interaksi Online. Vol. 1 No. 6

www.radarjogja.com/news

www.detik.com/news

www.uin-suka.ac.id/pengumuman

www.uin-suka.ac.id/akademik 